\title{
Richness and trophic guilds of carnivorous mammals in ejido Nuevo Becal, Calakmul, Campeche, Mexico
}

\author{
Marcos Briceño-Méndez ${ }^{1 *}$, Eduardo Naranjo², Gabriela Pérez-Irineo ${ }^{3}$, Yamili Contreras-Perera ${ }^{4}$, Elisa Sandoval-Serés ${ }^{5}$, and Mircea G. Hidalgo-
}

MIHART

'Secretaria de Medio Ambiente y Recursos Naturales del Estado de Campeche (SEMARNATCAM), Avenida Patricio Trueba de Regil, Calle Niebla Planta Alta. Fracciorama 2000, s/n, CP. 24090, San Francisco de Campeche, Campeche, México. Email: marc12_87@ hotmail.com (MABM).

${ }^{2}$ El Colegio de la Frontera Sur (ECOSUR), Unidad San Cristóbal, Carretera Panamericana y Periférico Sur s/n, CP. 29290, San Cristóbal de Las Casas. Chiapas, México. Email: enaranjo@ecosur.mx (ED).

${ }^{3}$ Departamento de zoología de invertebrados, Facultad de ciencias biológicas, Universidad Autónoma de Nuevo León, San Nicolás de los Garza, Nuevo León, México. Email: yamjaz 85@hotmail.com (YCP).

${ }^{4}$ Centro Universitario de Ciencias Biológicas y Agropecuarias, Universidad de Guadalajara. Km 15.5 Carretera a Nogales Las Agujas, CP. 45110, Zapopan. Jalisco, México. Email: esandovalseres@gmail.com (ESS).

${ }^{5}$ División Académica de Ciencias Biológicas, Universidad Juárez Autónoma de Tabasco. Km 0.5 Carretera Villahermosa-Cárdenas CP. 86039, Villahermosa. Tabasco, México. Email: mhidalgo@yahoo.com (MGH-M).

* Corresponding author

The prevalent and increasing situations such as the expansion of areas for agricultural use, livestock raising and hunting represent the most complex issues for the conservation of wild species. Mammals of the Order Carnivora are key species in ecosystems because they respond differently to changes in habitat. This study explored the species richness and composition of trophic guilds of the assemblage of the Order Carnivora in an area adjacent to Calakmul Biosphere Reserve, Mexico. From February 2014 to February 2015,10 stations with camera traps were set within the sub-evergreen tropical forest near water bodies, roads and trails. The structure of the carnivorous assemblage was evaluated through the species richness and trophic guild of species. The recording efficiency of traps was evaluated through the latency to first detection (LTD). A total of 76 photographic records were obtained for eight species of the Order Carnivora, as well as direct observations of three additional species, so the assemblage recorded was composed of 11 species. Four trophic guilds were identified: carnivores (5 species), omnivores (4), insectivores (1), and frugivores (1). The Order consists of two species of large predators (Panthera onca and Puma concolor) and three generalist species (Urocyon cinereoargenteus, Puma yagouaroundi, and Procyon lotor). P. concolor and Leopardus wiedii displayed a low LTD ( $<140$ days-trap). The eleven species recorded represent $26 \%$ of the species of this Order countrywise, and $64 \%$ for the state of Campeche. According to Mexican laws, $55 \%$ of Carnivore species are in a threatened category. The diversity of guilds was similar to other assemblages, particularly for the carnivorous and omnivorous guilds. The diversity observed in the Nuevo Becal region confirms its importance for the conservation of the Order Carnivora, and the relevance of the evaluation of wild population in areas adjacent to large reserves such as Calakmul.

Situaciones prevalentes y en aumento como la expansión de áreas para uso agrícola, la ganadería y la cacería representan los mayores problemas para la conservación de especies silvestres fuera de las áreas protegidas. Los mamíferos del Orden Carnivora son importantes en los ecosistemas debido a que responden de manera distinta a cambios en el hábitat. Este estudio se enfoca en conocer la riqueza de especies y composición de gremios tróficos del ensamblaje del Orden Carnivora en un área adyacente a la Reserva de la Biosfera de Calakmul, Campeche, México. Desde febrero de 2014 a febrero de 2015, 10 estaciones con fototrampas fueron establecidas dentro de la selva mediana sub-perennifolia en sitios cercanos a cuerpos de agua, caminos y brechas. La estructura del ensamblaje de carnívoros fue evaluada por medio de la riqueza específica y del gremio trófico de las especies. La eficiencia de las trampas en el registro fue evaluada mediante el cálculo del Tiempo de Latencia para la Primera Detección (LTD). Se obtuvieron 76 registros fotográficos independientes de 8 especies del orden Carnivora, además otras tres especies más fueron avistadas, por lo que en total fueron 11 especies. Los gremios tróficos fueron cuatro: carnívoros (5 spp.), omnívoro (4 spp.), insectívoro (1sp.), y frugívoro (1sp.). El Orden estuvo integrado por dos especies de depredadores de talla grande (Panthera onca y Puma concolor) y tres especies de hábitos generalistas (Urocyon cinereoargenteus, Puma yagouaroundi y Procyon lotor). Los valores de LTD para el registro de $P$. concolor y Leopardus wiedii fueron los más bajos (<140 días-trampa). Las 11 especies registradas representan el $26 \%$ de las especies de este orden a nivel nacional y el $64 \%$ para el estado de Campeche. La diversidad de gremios fue similar a otros ensamblajes, particularmente para el gremio carnívoro y omnívoro. El 55 \% de las especies se encuentra en alguna categoría de riesgo según la legislación mexicana. Esta diversidad en el ejido Nuevo Becal confirma su importancia para la conservación del orden Carnivora y la importancia de la evaluación de las poblaciones silvestres en áreas adyacentes a grandes reservas como la de Calakmul.

Key words: Calakmul; camera traps; carnivore; communal areas; conservation.

C 2017 Asociación Mexicana de Mastozoología, www.mastozoologiamexicana.org

\section{Introduction}

The accelerated deforestation and fragmentation of the primary vegetation, changes in land use, forest fires, selective logging, hunting and trafficking of wild flora and fauna represent the greatest threats to the conservation of wild species (Morin 2011). Investigating how species survive in landscapes modified by man is essential to understand the adaptations that are associated with this tolerance. 
In addition, it is also key to identify the species that warrant immediate conservation actions (Moreno 2006; Morin 2011). Changes in the local habitat can be evaluated through species richness (Morin 2011) and the diversity of trophic guilds, which are made up of species that use the same food resource in a similar way (Dayan and Simberloff 1991). Both features provide information on the structure of communities and the way in which species use the available resources through time.

The mammals of the Order Carnivora, in particular large predators, are key species and their elimination can lead to the overpopulation of some species and the decline of others; thus, carnivores play a key role in defining the structure of communities (Gittleman et al. 2001). Some of these species are important in areas that connect large ecological reserves, because they respond differently to changes in the habitat and show a wide ecological, morphological and behavioral diversity (Gittleman 1989).

Carnivores function as ecological indicators in an area, i.e., if carnivore populations are stable, this means there is enough food for their survival. The Order includes species that serve as "umbrella species", and contribute to the conservation of other species. However, there are also species that are at risk of conservation due to their vulnerability to impact by human activities, need for large areas with optimum habitat to survive, low reproductive rate and small population size (Gittleman et al. 2001).

The region of Calakmul, Campeche, includes one of the main remnants of Mexico's tropical forests, which along with the tropical forests of Chiapas, Quintana Roo and Petén in northern Guatemala and Belize, is part of one of the largest continuous forest in Mesoamerica. The area declared as the Calakmul Biosphere Reserve (RBC, for its acronym in Spanish) covers $7,231 \mathrm{~km}^{2}$ (SEMARNAT 2000). RBC includes a high diversity of mammal species, 13 of which belong to the Order Carnivora. Around RBC there are human settlements that have led to the accelerated deforestation and fragmentation of the primary vegetation, land-use changes, forest fires, selective logging, unregulated hunting, and illegal trafficking of wild flora and fauna (Secretaría de Ecología 2009). These disturbances have the potential to affect the connectivity of dispersion routes and genetic exchange of species within RBC with other conservation areas. Information on the diversity of species, including the Carnivora, is scarce in areas adjacent to $\mathrm{RBC}$, but nonetheless is required in management and conservation plans of these species. One of the largest adjacent areas is ejido Nuevo Becal to the southwest of RBC, with $520 \mathrm{~km}^{2}$ (Reyna-Hurtado 2009). The area comprises large areas of forest and water bodies that are necessary for the species, particularly during the dry season, but hunting is also practiced for both subsistence and sport purposes. The objective of this study was to estimate the richness of both species and trophic guilds belonging to the Order Carnivora at Nuevo Becal.

\section{Methods}

Study area. Ejido Nuevo Becal is located in the northeast portion of RBC between coordinates $\left(18.6920^{\circ} \mathrm{N}\right.$, $-89.2511^{\circ} \mathrm{W} ; 20.9450 \mathrm{~N}^{\circ},-89.6433 \mathrm{~N}^{\circ} ; 21.2811 \mathrm{~N},-89.6650^{\circ}$ $\left.\mathrm{W} ; 21.0161^{\circ} \mathrm{N},-89.8772^{\circ} \mathrm{W}, 18.6920^{\circ} \mathrm{N},-89.2511^{\circ} \mathrm{W}\right)$. The prevailing vegetation type is semi-evergreen tropical forest, with trees between 18 and $25 \mathrm{~m}$ high, also known as medium sub-evergreen forest (Pennington and Sarukhán 1998). Some intermediate associations are flooded forests, known locally as "lowlands" or "akalches" in Maya language, which are forests with trees between 8 and $15 \mathrm{~m}$ in height that are temporarily flooded because they are located in depressions on clayey soils (Reyna-Hurtado et al. 2010). Common species of plants include Brosimum alicastrum, Manilkara zapota, Pouteria campechiana, Ampelocera hottlei, Crataeva tapia, Citrullus vulgaris and Metopimu brownei (Pennington and Sarukhán 1998).

Altitude varies between 100 to $380 \mathrm{~m}$. The predominant climate is warm sub-humid with summer rainfall and with less than $60 \mathrm{~mm}$ of precipitation in the driest month. The mean annual temperature is $25^{\circ} \mathrm{C}$; the mean annual precipitation ranges between 1,200 and $1,500 \mathrm{~mm}$ in the central area, and from 1,500 to 2,000 $\mathrm{mm}$ in the south (García-Gil 2003).

Land tenure is predominantly community-owned. Productive activities include agriculture, livestock farming, beekeeping, and coal extraction; also practiced are subsistence hunting and, to a lesser extent, hunting (Weber 2000; Escamilla et al. 2000; Reyna-Hurtado and Tanner 2007; Santos-Fita et al. 2012; Briceño-Méndez et al. 2014; BriceñoMendez et al. 2016).

Field sampling. The study was conducted from February 2014 to February 2015 and used the camera-trap method coupled with indirect records of species. Cameras were in operation for 351 days. Ten permanent sampling stations were established within the forest in sites near surface water bodies (preferentially water bodies locally known as

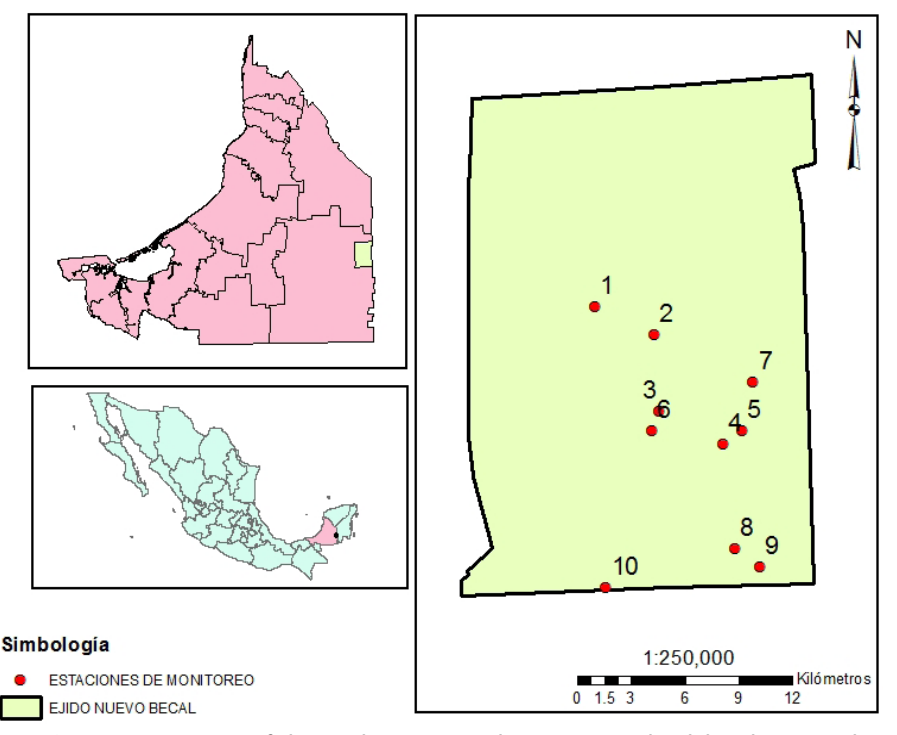

Figure 1. Location of the study area in ejido Nuevo Becal Calakmul, Campeche, Mexico. Red dots represent the monitoring stations. 
"aguadas"), roads or trails, chosen at random. The cameratraps used were Reconyx PC800 Hyperfire Professional IRTM and PC600 Hyperfire Pro White FlashTM (Reconyx, Inc., Holmen, Wisconsin, USA). Camera-traps were placed at a height not exceeding $50 \mathrm{~cm}$ from ground level and separated from each other by a distance of $1.5 \mathrm{~km}$ to $2.5 \mathrm{~km}$. An area of approximately $112 \mathrm{~km}^{2}$ was covered, based on the estimation of the minimum convex polygon formed by the external location of the traps (Reyna-Hurtado et al. 2016). The period of photographic records was set to be in operation for $24 \mathrm{~h}$, and recorded one individual images every 0.2 seconds. Camera traps were reviewed once a month and those that were misfunctioning were replaced.

The photographic records of each species obtained 24 hours apart were considered as independent events. However, when in subsequent photographs different individuals of the same species were observed, each individual was regarded as an independent record. To supplement the inventory and composition of guilds, records of observations and indirect effects observed during the walks to review camera traps were also taken into account. For the analysis, only the data obtained from camera traps were used. The identification of field tracks was carried out using the identification guides of Aranda-Sánchez (2012).

Data analysis. The collection effort of through cameratraps was expressed as the number of traps multiplied by the total number of days that these were in operation (traps * day; Medellín et al. 2006; Pérez-Irineo and Santos-Moreno 2013; Cruz-Jácome et al. 2015). The success of capture, expressed as percentage, was calculated using the total number of captures between the collection effort multiplied by 100 (Pérez-Irineo and Santos-Moreno 2013). The species richness was determined as the total number of species recorded, regardless of the method by which this number was obtained. The species richness obtained by cameras traps was estimated through asymptotic models for species accumulation curves (exponential and linear) from a matrix of the presence of species. The data matrix were randomized 100 times with the program Stimates version 9.0.0 (Colwell 2013). Asymptotic models were generated in the program STATGRAPHICS centurion version 17.0.0.

The efficiency of camera traps for recording each species was evaluated by calculating the latency to first detection (LTD). LTD was expressed as the collection effort deployed (trap-days) before obtaining the first record (Foresman and Pearson 1998; Pérez-Irineo and Santos-Moreno 2013). This allows estimating the approximate number of camera trapdays required to obtain records of the species in the study site (Foresman and Pearson 1998; Pérez-Irineo and SantosMoreno 2013).

To determine the trophic guild, each recorded species was classified according to the most frequently consumed food category. The classification was based on the one proposed by Van Valkenburgh (1989) and Dalerum et al. (2009), and the adjustments proposed by Perez-Irineo and SantosMoreno (2013), as well as on the description by Wilson and Mittermeier (2009). The classification was: 1) carnivores: consume mainly living terrestrial vertebrates, 2) frugivores: consume mainly fruits, 3 ) insectivores: consume insects and other terrestrial invertebrates, 4) scavengers: consume mainly the remains of dead animals, but may include other types of food, and 5) omnivores: show no preference to consume any specific food type (Pérez-Irineo and SantosMoreno 2013). In addition, the richness of each guild was quantified (Pérez-Irineo and Santos-Moreno 2013; CruzJácome et al. 2015). Photographs were handled and organized using the program Camera Base (version 1.6; Tobler 2014).

\section{Results}

The sampling effort was 3,510 trap-days and produced 76 independent photographic records, which correspond to a $2.6 \%$ sucess of capture, supplemented with 15 indirect records. A total of 11 species of the Order Carnivora were recorded, included in five Families (Table 1). The asymptotic models of species accumulation indicate that the model with the best fit was linear, with an estimate of 12.66 species (model parameters $a=5.87$ and $b=0.46$ ).

Three species were recorded indirectly during walks to review camera traps: skunk (Spilogale angustifrons; $n=6$ ), "martucha" (Potos flavus; $n=3$ ), and raccoon (Procyon lotor; $n=6)$. The species photographed were "cabeza de viejo" (Eira barbara; $n=1$ ), ocelot (Leopardus pardalis; $n=6$ ), margay (L. wiedii; $n=25$ ), jaguar (Panthera onca; $n=12$ ), puma (Puma concolor; $n=22)$, yagouaroundi ( $P$. yagouaroundi; $n=$ 1), badger (Nasua narica; $n=6$ ), and gray fox (Urocyon cinereoargenteus; $n=3$ ). For $P$. concolor and $L$. wiedii, the value of LTD was low (less than 140 trap-days); in contrast, U. cinereoargenteus and E. barbara attained a high LTD (greater than 2,000 trap-days; Figure 2).

Three trophic guilds were recorded for the Order Carnivora through photographs, plus one more through indirect observation. The carnivorous guild recorded the highest number of species, with five, followed by omnivorous

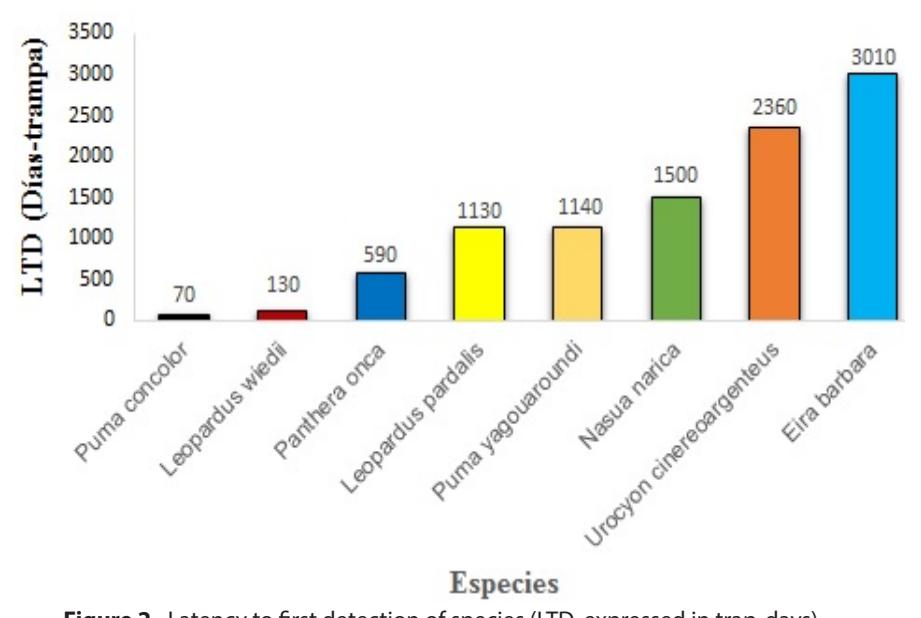

Figure 2. Latency to first detection of species (LTD, expressed in trap-days) 
with four and a single species for each of the insectivorous (S. angustifrons) and frugivorous (P. Flavus) guilds (Table 1). Of the 11 recorded species, six ( $55 \%$ ) are included in a risk category according to the Mexican Standard (SEMANART 2000): four, in danger of extinction (L. wiedii, L. pardalis, $P$. onca and E. barbara), one as threatened ( $P$. yagouaroundi), and one as under special protection (P. flavus; Table 1).

\section{Discussion and Conclusions}

Assemblage. In this study, the richness of Carnivora species was 11 species. Eight were recorded in less than 3,510 trap-days, which is equivalent to rgistering $72 \%$ of the species. This value of sampling effort was similar to the one reported in previous studies, with around 1,000 trap-days to register $40 \%$ of the species (Kelly and Holub 2008).

This value of sampling effort differs from other previous studies where a significant percentage of the representation of the species was obtained with a lower sampling effort, as was the case of The Salt Pond Mountain forest, Virginia, with 1,000 trap-days to represent $40 \%$ of the species (Kelly and Holub 2008); or the Peruvian Amazon forests, where $86 \%$ of the species were represented in 2,340 trapdays (Tobler et al. 2008). In contrast, in a high tropical forest at Los Chimalapas in southeastern Mexico, a much higher sampling effort was carried out (6,000 trap-days to obtain $83 \%$ of the species; Pérez-Irineo and Santos-Moreno 2013).

The Carnivora in ejido Nuevo Becal represent a group in a good conservation status; this is supported by the presence of predators and species that require relatively pristine environments, such as L. wiedii or P. flavus, in addition to the presence of large predators such as $P$. concolor and $P$. onca. The ejido has $33 \%$ of the species richness of Car-

Table 1. Species richness, trophic guilds and risk category of species of the Order Carnivora according to NOM-059-SEMARNAT-2010, in ejido Nuevo Becal, Calakmul, Campeche, Mexico. February 2014 to February 2015.

\begin{tabular}{|c|c|c|c|c|c|}
\hline Family & Species & $\begin{array}{l}\text { Common } \\
\text { Name }\end{array}$ & $\begin{array}{l}\text { Recording } \\
\text { method }^{\text {a }}\end{array}$ & $\begin{array}{l}\text { Trophic } \\
\text { Guild }^{b}\end{array}$ & $\begin{array}{l}\text { Risk } \\
\text { Category }\end{array}$ \\
\hline Felidae & Leopardus wiedii & $\begin{array}{l}\text { Tigrillo, } \\
\text { margay }\end{array}$ & $\mathrm{F}$ & C & $\begin{array}{l}\text { Danger of } \\
\text { Extinction }\end{array}$ \\
\hline Felidae & $\begin{array}{l}\text { Leopardus } \\
\text { pardalis }\end{array}$ & Ocelot & $\mathrm{F}$ & C & $\begin{array}{l}\text { Danger of } \\
\text { Extinction }\end{array}$ \\
\hline Felidae & Panthera onca & Jaguar & $\mathrm{F}, \mathrm{H}$ & C & $\begin{array}{l}\text { Danger of } \\
\text { Extinction }\end{array}$ \\
\hline Felidae & $\begin{array}{l}\text { Puma } \\
\text { yagouaroundi }\end{array}$ & Jaguarundi & $\mathrm{F}$ & C & Threatened \\
\hline Felidae & Puma concolor & Cougar & $\mathrm{F}$ & C & \\
\hline Mustelidae & Eira barbara & $\begin{array}{l}\text { Cabeza de } \\
\text { viejo }\end{array}$ & $\mathrm{F}$ & $\mathrm{O}$ & $\begin{array}{l}\text { Danger of } \\
\text { Extinction }\end{array}$ \\
\hline Canidae & $\begin{array}{l}\text { Urocyon } \\
\text { cinereoargenteus }\end{array}$ & Gray Fox & $\mathrm{Ob}$ & $\mathrm{O}$ & \\
\hline Procyonidae & Potos flavus & $\begin{array}{l}\text { Martucha, } \\
\text { kinkajou }\end{array}$ & $\mathrm{Ob}$ & $\mathrm{F}$ & $\begin{array}{l}\text { Special } \\
\text { protection }\end{array}$ \\
\hline Procyonidae & Nasua narica & Badger & $\mathrm{F}$ & $\mathrm{O}$ & \\
\hline Procyonidae & Procyon lotor & Raccoon & Obs, $\mathrm{H}$ & $\mathrm{O}$ & \\
\hline Mephitidae & $\begin{array}{l}\text { Spilogale } \\
\text { angustifrons }\end{array}$ & Skunk & $\mathrm{Ob}$ & 1 & \\
\hline
\end{tabular}

a Recording method: $\mathrm{F}=$ camera trap, $\mathrm{H}=$ tracks, $\mathrm{Ob}=$ observation.

${ }^{b}$ Trophic guild: $\mathrm{I}=$ insectivore, $\mathrm{O}=$ omnivore, $\mathrm{C}=$ carnivore, $\mathrm{F}=$ frugivore. nivora at a country level and $64 \%$ of the species richness in Campeche (Vargas-Contreras et al. 2014).

Generalist species such as $U$ cinereoargenteus, $P$. yagouaroundi and $P$. lotor showed high LTD values $(1,140,2,360$, and 3,010 trap-days, respectively, Figure 2) compared to other species (e. g., P. concolor and L. wiedii), so these can be considered rare in the study site. However, $U$ cinereoargenteus is frequently observed in the roads that lead to the entrance. These generalist species prefer open habitats and are adapted to disturbed areas (Servin and Chacon 2005; Valenzuela-Galván 2005. U cinereoargenteus was observed frequently in the roads that lead to the main entrance of ejido Nuevo Becal, probably as a result of the transformation of the forest to pasture or agricultural areas. These changes may impact the richness, composition or abundance of the Carnivora in the area. For example, it has been documented that $C$. latrans has spread to regions where its presence had not been recorded previously, mainly in areas where the forest has been altered (Hidalgo-Mihart et al. 2013).

Eleven species were observed, and the species accumulation model indicated that there were two species missing to register. The species that could be considered as missing are Bassariscus sumichrasti and Conepatus semistriatus because these are typical of tropical forests and there are previous studies that confirm their presence in Campeche (Vargas-Contreras et al. 2014). Several species were not recorded by camera traps likely due to the location and height of placement of traps in the understory. Arboreal species such as $B$. sumichrasti and those of small size, such as $S$. angustifrons and C. semistriatus, could not be recorded due to the height at which traps were placed, favoring the recording of medium-sized and larger species. Species such as S. angustifrons, P. flavus and P. lotor were recorded only through direct sightings, indicating that camera traps did not record all the species present in the ejido. The Order Carnivora in ejido Nuevo Becal was composed of four trophic guilds, with the greatest richness corresponding to carnivores and omnivores (five and four species, respectively). Frugivores and insectivores had only a single species each (P. flavus and S. angustifrons). This diversity of guilds was similar to the one recorded in other areas where there is a higher species richness for the carnivorous and omnivorous guilds (Van Valkenburgh 1989; Zapata et al. 2008) and a lower abundance of herbivores, frugivores and insectivores (Zapata et al. 2008; Dalerum et al. 2009; Pérez-Irineo and Santos-Moreno 2013). The richness of the carnivore guild in the study site can be associated to the high diversity of prey in the area. For example, there are regions where the richness of predators is associated to areas with high levels of herbivore biomass (Van Valkenburgh 1989; Zapata et al. 2008), and this number of species depends largely on the variety of available preys (Lopez-González and Miller 2002; Silva-Pereira et al. 2011). In this regard, the assessment of prey diversity is a research topic that deserves further investigations. 
It has been noted that communal areas adjacent to protected natural areas are important sites for the conservation of biodiversity, as the former maintain the connectivity between the latter (Vester et al. 2007). In addition, in certain cases communal areas may provide a greater proportion of essential resources (such as food and water) for the survival of species compared to natural protected areas. For example, it has been recently documented that ejido Nuevo Becal possesses a larger number of surface water bodies (locally called "aguadas") where higher relative abundances of the tapir Tapirus bairdii compared to RBC. This network of aguadas forms an essential complex for the use and displacement of T. bairdii across the region ( $\mathrm{O}^{\prime}$ Farrill et al. 2014; Sandoval-Serés et al. 2016; Reyna-Hurtado et al. 2016).

This study indicates that ejido Nuevo Bacal has a high diversity of the Carnivora, including large predators and species of other trophic guilds. More than half of these species (55\%) are classified in some risk category. Given the number of surface water bodies, the connectivity with $\mathrm{RBC}$, and the diversity of the Carnivora, it is recommended to focus conservation efforts toward ejido Nuevo Becal in order to maintain the large areas used for the activities of these species. Ejido Nuevo Becal is a clear example on the conservation of species outside protected areas.

\section{Literature cited}

Aranda-SÁnchez, M. J. 2012. Manual para el rastreo de mamíferos silvestres de México. Comisión Nacional para el Conocimiento y Uso de la Biodiversidad e Instituto de Ecología, A. C. Ciudad de México, México.

Briceño-Méndez, M. A., R. Reyna-Hurtado, S. Calme, and G. GarcíaGIL. 2014. Preferencias de hábitat y abundancia relativa de Tayassu pecari en un área con cacería en la región de Calakmul, Campeche, México. Revista Mexicana de Biodiversidad 85:242-250.

Briceño-Méndez, E. J. Naranjo, S. Mandujano, M. Altrichter, and R. Reyna-Hurtado. 2016. Responses of two sympatric species of peccaries (Tayassu pecari and Pecari tajacu) to hunting in Calakmul, Mexico. Tropical Conservation Science 9:1:11.

Castillo-Vela, G., J. A. Vargas-Contreras, G. Rivas-Hernández, and D. Antochiw. 2010. Mamíferos acuáticos. Pp. 362-371, in La Biodiversidad en Campeche: Estudio de Estado (VillalobosZapata, G. J., and J. Mendoza-Vega, eds.). Comisión Nacional para el Conocimiento y Uso de la Biodiversidad, Gobierno del Estado de Campeche, Universidad Autónoma de Campeche, San Francisco de Campeche, Campeche, México.

ColwelL, R. K. 2013. EstimateS: Statistical estimation of species richness and shared species from samples. Versión 9. 0. 0. University of Connecticut. Storrs, U. S. A. Disponible en: purl. oclc.org/estimates.

Cruz-Jácome, O., T. E. López, C. A. Delfín, and S. R. Mandujano. 2015. Riqueza y abundancia relativa de mamíferos medianos y grandes en una localidad en la Reserva de la Biosfera Tehuacán-Cuicatlán, Oaxaca, México. Therya 6:435-448.

Dalerum, F., E. Z. Cameron, K. Kunkel, and M. J. Somers. 2009. Diversity and depletions in continental carnivore guilds: implications for prioritizing global carnivore conservation.
Biology Letters 5:35-38.

Escalona-Segura, G., J. A. Vargas-Contreras, and L. Interián-Sosa. 2002. Registros importantes de mamíferos para Campeche, México. Revista Mexicana Mastozoología 6:166-170.

Escalona-Segura, G., and J. A. Vargas Contreras. 2010. Regionalización biológica del estado de Campeche. Pp. 110115, in La Biodiversidad en Campeche: Estudio de Estado (Villalobos-Zapata, G.J., and J. Mendoza-Vega, eds.). Comisión Nacional para el Conocimiento y Uso de la Biodiversidad, Gobierno del Estado de Campeche, Universidad Autónoma de Campeche. Campeche, México.

Escamilla, A., M. Sanvicente, M. Sosa, and C. Galindo. 2000. Habitat mosaic, wildlife availability, and hunting in the tropical forest of Calakmul, México. Conservation Biology 14:1592-1601.

Foresman, K. R., AND D. E. Pearson. 1998. Comparison of proposed survey procedures for detection of forest carnivores. Journal of Wildlife Management 62:1217-1226.

GARCíA-GIL, G. 2003. Colonización humana reciente y formación del paisaje agrario en la Reserva de la Biosfera de Calakmul, Campeche, México. Tesis de doctorado. Facultad de Filosofía y Letras. Universidad Nacional Autónoma de México. Ciudad de México, México.

GitTleman, J. L. 1989. Carnivore behavior, ecology, and evolution. Cornell University Press. Nueva York, U. S. A.

Gittleman, J. L., S. M. Funk, D. W. Macdonald, and R. K. Wayne. 2001. Why "carnivore conservation"? Pp. 1-8, in Carnivore conservation (Gittleman, J. L., S. M. Funk, D.W. Macdonald, and R. K. Wayne, eds.). Cambridge University Press. Cambridge, Reino Unido.

Hidalgo-Mihart, M. G., F. M. Contreras-Moreno, L. A. Pérez-Solano, and C. Hernandez-Lara. 2013. Primeros registros de coyote (Canis latrans) en Campeche, México. Revista Mexicana de Biodiversidad 84:1012-1017.

KeLLy, M. J., AND E. L. Holub. 2008. Camera trapping of carnivores: trap success among camera types and across species, and habitat selection by species, on Salt Pond Mountain, Giles County, Virginia. Northeastern Naturalist 15:249-262.

López-González C. A., And B. J. Miller. 2002. Do jaguars (Panthera onca) depend on large prey? Western North American Naturalist 62:218-222.

Medellín, R., D. Azuara, L. Maffel, H. Zarza, H. Barcenas, E. Cruz, R. Legaría, I. Lira, G. Ramos-Fernández, and S. Ávila. 2006. Censos y Monitoreo. Pp. 25-35, in El Jaguar Mexicano en el Siglo XXI: Situación Actual y Manejo (Chávez, C., and G. Ceballos, eds.). CONABIO-ALIANZA WWF TELCEL-Universidad Nacional Autónoma de México. Ciudad de México, México.

Miller, B. J., B. Dugelby, D. Foreman, D. M. Rio, R. Nooss, M. Phillips, R. Reading, M. E. Soule, J. Terborgh, and L. Willcox. 2001. The importance of large carnivores to healthy ecosystems. Endangered Species 18:202-210

Morales, R., and S. Magaña. 2001. Fuentes de impacto, necesidades de investigación científica y monitoreo en Calakmul, Campeche. Pronatura Península de Yucatán, A. C. and The Nature Conservancy.

MoReno, R. S. 2006. Parámetros poblacionales y aspectos ecológicos de los felinos y sus presas en Cana, Parque Nacional Darien, Panamá. Tesis de maestría. Universidad Nacional sistema de estudios de posgrado instituto internacional en conservación y manejo de vida silvestre. Heredia, Costa Rica. 
Morin, P. J. 2011. Community Ecology, segunda edición. WileyBlackwell. Nueva Jersey, U. S. A.

O' Farrill, G., K. Gauthier Schampaert, B. Rayfield, O. Bodin, and S. CALME'. 2014. The Potential Connectivity of Waterhole Networks and the Effectiveness of a Protected Area under Various Drought Scenarios. PLoS ONE 9:5

Pérez-Irineo, G., And A. Santos-Moreno. 2013. Riqueza de especies y gremios tróficos de mamíferos carnívoros en una selva alta del sureste de México. Therya 4:551-564.

Pennington, T., and J. Sarukhán. 1998. Árboles Tropicales de México. Universidad Nacional Autónoma de México y Fondo de Cultura Económica. Ciudad de México, México.

ReID, A. F. 1997. A field guide to the mammals of Central America and Southeast Mexico. Oxford University Press. Nueva York, U. S. A.

ReYna-Hurtado, R., AND G. TANner. 2007. Ungulate relative abundance in hunted and non-hunted sites in Calakmul forest (Southern Mexico). Biodiversity and Conservation 16:743-756.

Reyna-Hurtado, R. 2009. Conservation status of the whitelipped peccary (Tayassu pecari) outside the Calakmul Biosphere Reserve in Campeche, Mexico: a synthesis. Tropical Conservation Science 2:159-172.

Reyna-Hurtado R. Á., G. O’Farrill, D. Sima, M. Andrade, A. Padilla, AND L. SosA. 2010. Las aguadas de Calakmul. CONABIO/ Biodiversitas 93:1-5.

Reyna-Hurtado, R., M. Sanvicente- López, J. Pérez-Flores, N. CarrilloREYNA, AND S. CALME'. 2016. Insights into the multianual home range of a Baird's tapir (Tapirus bairdii) in the Maya Forest. Therya 7:271-276.

Sandoval-Seres, E., R. Reyna-Hurtado, M. Briceño-Méndez, and R. de la Cerda Vega. 2016. Uso de aguadas y abundancia relativa de Tapirus bairdii en la región de Calakmul, Campeche, México. Therya 7: 39-50.

Santos-Fita, F. D., E. J. Naranjo, and R. Salazar. 2012. Wildlife uses and hunting patterns in rural communities of the Yucatan Peninsula, Mexico. Journal of Ethnobiology and Ethnomedicine 8:1-38.

Semarnat. 2000. Programa de manejo de la Reserva de la Biosfera de Calakmul. México. Instituto Nacional de Ecología. Ciudad de México, México.

Semarnat. 2010. Norma Oficial Mexicana NOM-059-Ecol-2010. Protección ambiental, especies nativas de México de flora y fauna silvestres, categorías de riesgo y especificaciones para su inclusión, exclusión o cambio. Lista de especies en riesgo. Diario Oficial de la Federación, 30 diciembre 2010.

Secretaria de Ecología. 2009. Programa de conservación y manejo de la zona sujeta a conservación ecológica BalamKu. Gobierno del estado de Campeche. Campeche, México.

Servín, J., and E. Chacón. 2005. Urocyon cinereoargenteus. Pp. 354-355, in Los mamíferos silvestres de México (Ceballos, G., and G. Oliva, eds.). Comisión Nacional para el Conocimiento y Uso de la Biodiversidad y Fondo de la Cultura Económica. Ciudad de México, México.

Simberloff, D., AND T. Dayan. 1991. The guild concept and the ecological communities. Annual Reviews Ecology and Systematics 22:115-143.

Silva-Pereira, J. E., R. F. Moro-Rios, D. R. Bilski, and F. C. Passos. 2011. Diets of three sympatric Neotropical small cats: food niche overlap and interspecific differences in prey consumption. Mammalian Biology 76:308-312.

Tobler, M. W., S. E. Carrillo-Percastegui, R. Leite Pitman, R. Mares, AND G. Powell. 2008. An evaluation of camera traps for inventorying large-and medium-sized rainforest mammals. Animal Conservation 11:169-178.

Toblen, M. 2014. Camera base user guide. Available at: http:// www.gnu.org/licenses/.

Valenzuela-Galván, D. 2005. Procyon lotor. Pp. 415-417, in Los mamíferos silvestres de México (Ceballos, G., and G. Oliva, eds.). Comisión Nacional para el Conocimiento y Uso de la Biodiversidad y Fondo de la Cultura Económica. Ciudad de México, México.

Van Valkenburgh, B. 1989. Carnivore dental adaptations and diet: a study of trophic diversity within guilds. Pp. 410-436, in Carnivore, behavior, ecology, and evolution (Gittleman, J. L., eds.). Cornell University Press. Nueva York, U. S. A.

Vargas-Contreras, J.A., J. Arroyo-Cabrales, M. Sanvicente-López, and R. Reyna-HuRtado. 2002. Nuevos registros de mamíferos para Campeche. Vertebrata Mexicana 11:17-20.

Vargas-Contreras J. A., G. Escalona-Segura, D. Guzmán Soriano, O. G. Retana Guiascón, H. Zarza, and G. Ceballos. 2014. Los mamíferos del estado de Campeche. Revista Mexicana de Mastozoología Nueva Época 4:60-74.

Vester, H. F., M. D. Lamrence, J. R. Eastman, B. L. Turner, S. Calmé, R. Dickson, C. Pozo, and F. Sangermano. 2007. Land change in the southern Yucatán and Calakmul Biosphere Reserve: Effects on habitat and biodiversity. Ecological Applications 17:9891003.

WEBER, M. 2000. Effects of hunting on tropical deer populations in southeastern México. Tesis de maestría. Royal Veterinary College, University of London. Londres, United Kindom.

Wilson, D. E., and R. A. Mittermeier. 2009. Handbook of the mammals of the world. Carnivores. Lynx editions. Barcelona, España.

Zapata, S. C., A. Travaini, M. Delibes, and R. Martínez-Peck. 2008. Identificación de morfogremios como aproximación al estudio de reparto de recursos en ensambles de carnívoros terrestres. Mastozoología Neotropical 15:85-101.

\section{Associated editor: Lia Mendez}

Submitted: December 26, 2016; Reviewed: January 20, 2017;

Accepted: May 25, 2017; Published on line: May 29, 2017. 